Uniwersytet im. Adama Mickiewicza w Poznaniu

\title{
Mechanizmy zwiększania partycypacji kobiet w wyborach
}

\section{Wstęp}

otychczasowe badania dotyczące sposobów zapewnienia odpowiedniej reprezentacji kobiet $\mathrm{w}$ organach władzy państwowej można uznać za wciąż rozwijające się. W ostatnim okresie, mniej więcej od połowy poprzedniego dziesięciolecia, nastąpił znaczny wzrost zainteresowania problemem. Od ukazania się raportu Polityka równości ptci. Polska 2007 (Program Narodów Zjednoczonych ds. Rozwoju, 2007) również w Polsce coraz większa grupa naukowców poświęca swą uwagę zagadnieniom wzrostu partycypacji kobiet w sferze polityki.

Szczególnie przydatne w prowadzonej analizie okazują się metody badawcze stosowane w politologii, socjologii i naukach prawnych. Poczynając od analizy aktów prawnych i dokumentów źródłowych, poprzez analizę statystyczną aż do analizy systemowej.

Ważnym czynnikiem wpływającym na prawdopodobieństwo wyboru kobiet do władz ustawodawczych jest system wyborczy obowiązujący w danym kraju. W niniejszym opracowaniu skoncentrujemy się wyłącznie na prawnych regulacjach prowadzących do zapewnienia, niekiedy w sposób sztuczny, odpowiedniej reprezentacji kobiet.

Problem zwiększenia reprezentacji kobiet w życiu politycznym znalazł chwilowo swoje rozwiązanie przez zastosowanie różnego rodzaju reguł, które mają zapewnić większą reprezentację pań w strukturach politycznych. Zastosowanie ,technicznych” rozwiązań stanowi tylko przejściowe i doraźne złagodzenie problemu niedoreprezentowania jednej płci w organach państwowych. Niemniej jednak warto wskazać na możliwe kierunki działań o charakterze prawnym zmierzające do wzrostu reprezentacji kobiet w organach władzy państwowej oraz przedstawienie ich konsekwencji, zarówno tych pozytywnych, jak i negatywnych. 


\section{Partycypacja polityczna kobiet}

Można wyróżnić przynajmniej kilka czynników mających wpływ na zwiększenie partycypacji kobiet w polityce. Bez wątpienia należą do nich:

- emancypacja kobiet w różnych sferach życia;

- zwiększenie zainteresowania kobiet sprawami publicznymi;

- wzrost poziomu wykształcenia kobiet;

- coraz większe nastawienie kobiet na karierę zawodową i społeczną;

- zmiana postrzegania roli kobiet w życiu społecznym;

- upowszechnienie partnerskiego modelu funkcjonowania rodziny;

- rozwój studiów genderowych.

Partycypacja polityczna kobiet może być rozpatrywana w kilku płaszczyznach. Po pierwsze jest to udział kobiet w tych działaniach, które służą do tworzenia reprezentacji politycznej. Przede wszystkim są to procedury wyborcze. Minimum zaangażowania na tym poziomie, to udział w głosowaniu, czyli korzystanie z czynnego prawa wyborczego.

Druga płaszczyzna, to sposób głosowania, czyli czym kieruje się wyborca dokonując rozróżnienia pomiędzy opcjami programowymi i personalnymi. Pojawia się pytanie, czy płeć kandydata ma tutaj większe znaczenie niż np. jego program polityczny lub formacja polityczna którą reprezentuje.

Płaszczyzna trzecia dotyczy korzystania z biernego prawa wyborczego. Na ile kobiety są skłonne do czynnego zaangażowania się w działalność polityczną. Czy przystępując do rywalizacji wyborczej są skłonne poświęcić się działalności publicznej i traktować ją jako sposób na życie. Czy mają świadomość konsekwencji związanych z dokonaniem takiego wyboru. Na te wszystkie pytania można odpowiedzieć kolejnym pytaniem. Czym różnią się motywacje kobiet od motywacji mężczyzn, podejmujących decyzję o czynnym uczestnictwie w życiu politycznym i wyborze takiej właśnie drogi kariery zawodowej. Odpowiedź zdaje się być prosta. W zasadzie niczym. W jednym i drugim przypadku najważniejsze jest, aby decyzja była dobrze przemyślana, oparta na prawdziwych i racjonalnych przesłankach i aby zdawać sobie sprawę z konsekwencji, które są efektem stania się osobą publiczną. Można jedynie domniemywać, iż kobietom jest znacznie trudniej funkcjonować w sferze realnej polityki, ponieważ natrafiają one nadal na mur stereotypów uznających politykę za domenę mężczyzn.

Płaszczyzna czwarta dotyczy technik wyborczych. Oczywiście nie mają one żadnego znaczenia dla kandydatek i kandydatów, jeżeli nie 
wprowadza się specjalnego rozróżnienia zasad czy chociażby technik wyborczych ze względu na płeć. Można jednak zastosować odmienne rozwiązania dla kandydatów kobiet i mężczyzn. Niekiedy wprowadza się modyfikacje ogólnych zasad dla kandydatów określonej płci. W ten sposób można różnicować szanse poszczególnych kandydatów w wyborach ze względu na określone uwarunkowania, w tym także ze względu na płeć. Takie praktyki zawsze będą budziły wątpliwości, ponieważ naruszają zasadę jednakowych szans dla wszystkich kandydatów. Można jednak spojrzeć na problem z innego punktu widzenia. Przyczyną szczególnych preferencji dla niektórych kandydatów może być przyjęcie zasady wyrównywania szans. Tym samym wprowadzone szczególne preferencje spełniają specyficzne zadanie. Umożliwiają w praktyce stworzenie identycznych szans dla różnych kategorii kandydatów. Brak takich preferencji oznaczałby ograniczenie możliwości korzystania z jednakowych uprawnień przez wszystkie grupy kandydatów. Tak więc szczególne traktowanie określonej grupy w praktyce może oznaczać wyrównanie jej szans w porównaniu do pozostałych grup społecznych, które de facto uzyskały przewagę nad inną lub innymi grupami. Takie postawienie problemu zawsze będzie jednak budziło kontrowersje i zastrzeżenia. Pojawi się bowiem pytanie, czy inne grupy, z innych powodów, nie są też dyskryminowane i czy wobec nich nie powinno zastosować się zasady wyrównywania szans. Może pojawić się żądanie proporcjonalnego udziału w sprawowaniu władzy różnych grup wiekowych, środowiskowych, etnicznych, religijnych, narodowych, zawodowych itd. Eskalacja takich żądań może w konsekwencji doprowadzić do poważnego rozstroju systemu politycznego.

\section{Elementy systemu wyborczego mające wplyw} na reprezentację kobiet

Najwygodniejszym sposobem doprowadzenia do parytetu płci w wybieralnych organach państwowych jest zastosowanie formalnych, a więc wynikających z regulacji prawnych, rozwiązań. Do najpopularniejszych $\mathrm{z}$ nich dzisiaj należą kwoty, czyli ustalone z góry liczby reprezentantów konkretnej płci na listach wyborczych. Kwoty mogą być wzmocnione zastosowaniem „metody suwakowej”, czyli tzw. „zebrą” na etapie tworzenia list wyborczych, czy ustaleniem pewnego limitu procentowego np. wyznaczającego udział kandydatów kobiet i mężczyzn na poszczególnych pozycjach list kandydatów. 
Można również ustalić kwoty na poziomie wyników wyborów, co jest metodą najbardziej skuteczną. Jedną z form kwot mandatowych może być osobna lista kobieca lub system najlepszego przegranego. W praktyce stosowane są również kompilacje wspomnianych metod.

Osobnym problemem jest dobór odpowiedniego systemu wyborczego, wielkość okręgów wyborczych oraz przyjęta formuła wyborcza. Można postawić tezę, iż zastosowanie konkretnych rozwiązań ma istotny wpływ na osiągnięcie planowanych efektów, w tym także parytetu płci. Odpowiednie manipulowanie prawem wyborczym ma istotny wpływ na końcowe rezultaty elekcji. Trzeba tylko wiedzieć jakie mechanizmy najlepiej służą uzyskaniu pożądanych rezultatów.

Należy wskazać także na „techniczne” uwarunkowania udziału kobiet w procesach wyborczych. Pierwszym etapem jest zawsze selekcja kandydatów. We współczesnych demokracjach mamy do czynienia z partiokracja. To partie są głównymi aktorami na scenie politycznej. One określają i dyktują warunki gry politycznej. One też określają zasady i mechanizmy rządzące procedurami partycypacyjnymi. Stąd też to do partii politycznych należy ostateczna decyzja dotycząca kierunków rozwoju demokracji i jej form. To partie, niekiedy pod presją opinii publicznej lub jej istotnej części, podejmują decyzje o preferencji dla niektórych grup społecznych. Tak stało się np. w 1993 roku w Polsce, kiedy do ordynacji wyborczej do Sejmu wprowadzono tzw. progi zaporowe. Jednocześnie ustawodawca zwolnił z obowiązku przekraczania progu zaporowego komitety wyborcze organizacji mniejszości narodowych. Ta zasada obowiązuje do dziś ${ }^{2}$. $\mathrm{Z}$ tego przywileju dotychczas korzystała, i korzysta nadal, tylko jedna mniejszość narodowa w Polsce, mniejszość Niemiecka. Niemniej jednak przepis dotyczy wszystkich zarejestrowanych w Polsce mniejszości narodowych.

Za argument przemawiający za umieszczaniem coraz większej liczby kobiet na listach wyborczych należy uznać tendencję do stwarzania wyborcy szerokiego wachlarza oferty do wyboru. Tym samym obok innych możliwości dokonania wyboru kandydatów ze względu na profesję, styl bycia, miejsce zamieszkania, wykształcenie, wyznawany światopogląd, wiek itd. powinna pojawiać się coraz częściej opcja dokonania wyboru także ze względu na płeć. Stwarzanie takiej możliwości w niczym nie

1 Ustawa z dnia 5 stycznia 2011 r. Kodeks wyborczy, Dz. U. 2011, Nr 21, poz. 112 , art. $197, \S 1$. 
ogranicza szans komitetu wyborczego na uzyskanie dobrego wyniku, a często wręcz te szanse zwiększa.

Inaczej kwestia ta przedstawia się w systemach wyborczych opartych na jednomandatowych okręgach wyborczych. W tym przypadku ryzyko komitetu wyborczego jest znacznie większe. Może bowiem zdarzyć się tak, iż część wyborców tradycyjnie głosujących na kandydata danego ugrupowania wstrzyma się od głosowania lub przeniesie głos na inne ugrupowanie, ponieważ nie będzie chciało wesprzeć kobiety. Z drugiej jednak strony można wyobrazić sobie dokładnie odwrotny mechanizm. Na kandydatkę zagłosują dodatkowe osoby, które podjęły właśnie taką decyzję ze względu na to, że kandyduje kobieta, a nie mężczyzna. Wybór i ryzyko należy zawsze do komitetu wyborczego.

W systemie rozdrobnienia partyjnego, takim jaki występuje także w Polsce, oraz proporcjonalnym systemie wyborczym do Sejmu powstały korzystne okoliczności do zwiększania udziału kobiet w rywalizacji wyborczej. Nic bowiem nie stoi na przeszkodzie umieszczaniu nazwisk kandydatek na listach wyborczych, skoro listy są obszerne, a wyborca i tak wskazuje preferencję tylko w stosunku do jednego kandydata. Każdy głos oddany na któregokolwiek kandydata z listy jest zyskiem dla komitetu wyborczego i tym samym przyczynia się do zwiększenia jego sukcesu wyborczego. Problem może dotyczyć czegoś innego, a mianowicie znalezienia odpowiednio dużej liczby kobiet chętnych do kandydowania.

\section{Charakter prawa wyborczego a partycypacja polityczna kobiet}

\section{Wielomandatowe okręgi wyborcze}

Ustalenie proporcji reprezentacji płci w okręgach wielomandatowych nie nastręcza większych problemów technicznych. Najprostszym sposobem jest system kwoty ptci (system kwotowy). Ale tylko pozornie stanowi on najskuteczniejszy mechanizm zapewniający równość szans kobiet i mężczyzn.

Pierwsza kwestia to ustalenie proporcji. W publicystyce, ale niekiedy również w literaturze przedmiotu, pojawia się określenie parytet. W praktyce tylko w nielicznych przypadkach na świecie mamy do czynienia z takim rozwiązaniem. Oznacza ono, iż miejsca na listach kandydatów, lub jeszcze rzadziej mandaty, są dzielone w równych liczbach pomiędzy kobiety i mężczyzn. 
Znacznie częściej stosowany jest tak zwany system kwotowy. Polega on na określeniu, najczęściej w ujęciu procentowym, proporcji pomiędzy kobietami a mężczyznami na listach wyborczych lub w organie wybieralnym. Najprościej jest to uczynić na etapie zgłaszania kandydatów. Zasadą będzie wtedy umieszczenie na listach kandydatów kobiet i mężczyzn w określonych z góry proporcjach. Pojawiają się tu jednak istotne problemy, np. czy ustalone kwoty dotyczą konkretnie kobiet, czy obydwu płci. W tym drugim przypadku wymóg oznaczałby, iż na listach kandydatów musi znajdować się minimum określona liczba osób jednej płci. Takie rozwiązanie jest stosowane częściej, np. w polskim Kodeksie wyborczym z 2011 roku$^{2}$. W praktyce może to sprawiać pewien kłopot, jak np. Partii Kobiet, która na swoich listach wyborczych będzie musiała zapewnić minimum 35\% miejsc dla mężczyzn.

O ile nie powinno być problemem spełnienie wymogów kwotowych na poziomie zgłaszania kandydatów, to rodzi się pytanie o ich skuteczność, jeżeli weźmiemy pod uwagę wynik wyborów. Znaczny wpływ na wyniki głosowania ma miejsce na liście, na którym zostało umieszczone nazwisko kandydata. Chodzi tu nie tylko o względy prestiżowe, ale przede wszystkim o szanse uzyskania mandatu.

Analizując powyższe uwarunkowania należy rozważyć dwojaką możliwość rozstrzygania wyników głosowania. W pierwszym przypadku weźmiemy pod uwagę zasadę list zamkniętych. Oznacza ona, iż mandaty są przydzielane kandydatom w kolejności umieszczenia ich nazwisk na liście do głosowania. Mandaty uzyskują ci z nich, których nazwiska zostały umieszczone na początku listy i mieszczą się w liczbie mandatów przypadających danej liście.

Drugi rodzaj rozstrzygnięcia to tzw. listy otwarte. Wyborca może wskazać nie tylko listę na którą oddaje swój głos, ale dodatkowo wskazuje również konkretnego kandydata, którego popiera. W tym rozwiązaniu, przynajmniej teoretycznie, kolejność umieszczenia nazwisk na liście kandydatów nie ma znaczenia. Mandaty bowiem otrzymują ci kandydaci, którzy kolejno uzyskali największą liczbę głosów i mieszczą się w liczbie mandatów, które uzyskała dana lista.

W obydwu przypadkach, chociaż w większej mierze dla list zamkniętych, w praktyce istotne znaczenie ma kolejność umieszczenia nazwisk na liście kandydatów. Stąd system kwotowy musi być uzupełniony o zasady

2 Ibidem, art. 211, § 3. 
umieszczania nazwisk kandydatów na listach. W rzeczywistości spotyka się w tej kwestii różne rozwiązania. Pierwsze polega na braku regulacji. Czyli komitet wyborczy ustala układ kandydatów na liście bez konieczności zachowania zasad umieszczania nazwisk kandydatek i kandydatów w określonej kolejności czy innych reguł. Taki system aktualnie obowiązuje w Polsce.

Inny sposób to określenie wskaźników reprezentacji płci w kolejnych częściach listy kandydatów. Najczęściej pojawiają się wymogi umieszczenia w pierwszej trójce, piątce czy dziesiątce kandydatów określonej liczby przedstawicieli jednej płci.

Rozwiązaniem uważanym za najbardziej pożądane jest tzw. metoda suwakowa (zebra). Polega ona na naprzemiennym umieszczaniu nazwiska kobiety i mężczyzny. Trzeba jeszcze tylko zdecydować, czy zaczynamy od nazwiska kobiety czy mężczyzny. W praktyce stosowana jest najczęściej zasada wzajemności. W co drugim okręgu wyborczym na czele listy umieszcza się nazwisko kobiety. Ta zasada może być niezwykle ważna dla wyrównania szans kobiet. Z doświadczenia wiemy, iż statystycznie najwięcej głosów w wyborach do Sejmu w Polsce uzyskują kandydaci, których nazwiska znajdują się na pierwszym miejscu listy kandydatów. Oczywiście jest to pewna prawidłowość, a nie sztywna zasada. Można przytoczyć wiele przypadków, kiedy mandat uzyskały osoby z dalszych miejsc na liście, a nie uzyskał go kandydat z pierwszego miejsca.

W systemach wyborczych, w których wprowadzono tzw. progi zaporowe, a więc wymóg uzyskania określonego poziomu poparcia wyborców, aby komitet mógł uczestniczyć w podziale mandatów, mogą pojawić się utrudnienia w umieszczaniu kobiet na listach kandydatów. Wydaje się bowiem, iż im większa liczba znanych z działalności politycznej lub innych form aktywności osób zostanie umieszczonych na listach kandydatów, tym bardziej wzrastają szanse na uzyskanie większej liczby głosów. To założenie sprawdza się w rzeczywistości, ale wcale nie jest efektem umieszczania na listach kandydatów nazwisk znanych mężczyzn. W tym samym stopniu odnosi się również do znanych i rozpoznawalnych kandydatek. Tym samym trudno za przeszkodę w umieszczaniu na listach wyborczych nazwisk kobiet uznać obawę o nie przekroczenie przez komitet wyborczy określonego ustawowo progu poparcia społecznego, wymaganego dla uzyskania prawa do udziału w podziale mandatów. I tak wyborcy głosują na konkretną listę. Ewentualnie niektórzy z kandydatów uzyskają niewielką liczbę głosów. 


\section{Jednomandatowe okręgi wyborcze}

Inaczej ten mechanizm funkcjonuje w systemie okręgów jednomandatowych, tak jak to ma miejsce w wyborach do Senatu. W tym systemie komitet wyborczy decyduje się na wystawienie jednego, najmocniejszego kandydata, czyli takiego, który ma największe szanse na odniesienie sukcesu, czyli zebranie największej liczby głosów. Ponieważ, statystycznie rzecz ujmując, mężczyźni dysponują większym doświadczeniem w działalności politycznej i częściej się w nią angażują, następuje proces wyparcia kobiet z rywalizacji o mandaty. Oczywiście mowa jest tutaj o pewnym zjawisku w skali ogólnej. Znane są przypadki, kiedy to kobiety są postrzegane jako najlepsze kandydatki do mandatu i pozostawiają mężczyzn poza konkurencją. Stworzenie jednak systemu, który gwarantowałby równe szanse kobietom i mężczyznom w tej rywalizacji jest bardzo trudne, chociaż we wcześniejszej części niniejszego opracowania na takie rozwiązania wskazywano.

Wystawienie w rywalizacji opartej na systemie większościowym, szczególnie z okręgami jednomandatowymi, kandydatów, którzy nie są najmocniejsi w konkurowaniu z innymi, oznacza ryzyko zmarnowania głosów swoich wyborców. Zachodzi bowiem obawa, że przeniosą oni swoje głosy na kandydata innej formacji politycznej lub powstrzymają się od udziału w głosowaniu.

Jednomandatowe okręgi wyborcze zdecydowanie nie sprzyjają zwiększeniu reprezentacji kobiet. Już na etapie zgłaszania kandydatów pojawiają się poważne problemy. Komitety wyborcze zgłaszają w każdym okręgu tylko jednego kandydata. Jest nim osoba mająca, zdaniem komitetu, największe szanse na zwycięstwo. Ponieważ w większości przypadków taki wymóg spełnia raczej sprawdzony już działacz polityczny, to on ma największe szanse na sukces wyborczy. Tym samym konkurencyjność wchodzącego dopiero do polityki kandydata jest znacznie mniejsza. Oczywiście te prawidłowości nie są zależne od płci kandydatów, ale ponieważ dotychczas polityka była raczej domeną mężczyzn, to kobiety mają mniejsze szanse.

Można przezwyciężać taką tendencję, jeżeli jest taka wola decydentów w komitecie wyborczym. Dobrym przykładem przyjęcia takich rozwiązań jest Wielka Brytania. „Wprowadzono tam tzw. kobiece listy kandydatów. Listy najpoważniejszych kandydatów składają się z potencjalnych kandydatów, z których partia wybiera ostatecznego kandydata. Kobiece listy składają się wyłącznie z potencjalnych kandydatek i mają być stosowane 
w połowie okręgów bezpiecznych dla Laburzystów tam, gdzie poseł wycofał się z polityki, a także w połowie okręgów, gdzie są minimalne szanse powodzenia. Innym rodzajem kwot, który można umieścić na skali między kategorią kwot dotyczących osób ubiegających się o miejsce na liście a kategorią kwot dotyczących proporcji kandydatów i kandydatek na listach, jest zastosowany z powodzeniem przez Szkocką Partię Pracy system okręgów bliźniaczych. Polega on na łączeniu w pary okręgów wyborczych - w jednym wybiera się kobietę, w drugim mężczyznę, żeby osiagnąc zrównoważoną reprezentację. Model ten zastosowano po raz pierwszy w wyborach do parlamentu Szkocji w 1999 roku, lecz później od niego odstapiono" (Komisja Praw Kobiet i Równouprawnienia Parlamentu Europejskiego, 2008, s. 16-17).

Tylko w co trzecim państwie na świecie, mającym większościowy system wyborczy, wprowadzono jakiś rodzaj kwot dotyczących płci, w porównaniu do czterech piątych krajów mających proporcjonalny system wyborczy (Dahlerup, 2007, s. 80-81).

Jakimś, połowicznym i przejściowym, rozwiązaniem może być chociażby wprowadzenie zasady, iż na etapie wyłaniania kandydatów kierownictwo partii będzie miało obowiązek brania pod uwagę dwoje kandydatów do nominacji.

Struktura głosowania w systemie większościowym w okręgach wielomandatowych

Sytuacja zmienia się również w zależności od tego, czy mamy do czynienia z wyborami opartymi na zasadzie większości względnej, czy bezwzględnej.

W pierwszym z wymienionych systemów ryzyko wystawienia kandydatów, którzy zdaniem komitetu wyborczego mają mniejsze szanse powodzenia, jest mniejsze, ponieważ głosy wyborców mogą zostać skoncentrowane na silniejszych kandydatach i tym samym zwiększają ich szansę powodzenia. Jednakże rozproszenie głosów pomiędzy większą liczbę kandydatów powoduje osłabienie tych najsilniejszych. W analizowanym systemie głosowania istotna także jest liczba głosów, którą dysponuje wyborca. Jeżeli jest to tylko jeden głos, to sytuacja jest o tyle niebezpieczna, iż głosy mogą rozproszyć się pomiędzy różnych kandydatów z tej samej listy i osłabi to wyniki najmocniejszych z nich.

Inaczej kształtuje się sytuacja w przypadku dysponowania przez wyborcę większą liczbą głosów. Najczęściej jest to taka sama liczba głosów 
ilu wybiera się przedstawicieli z danego okręgu wyborczego. Wtedy szanse każdego z kandydatów są podobne. Rozkład głosów między kandydatów jest oczywisty. Zgłoszenie kobiet zwiększa szansę ich poparcia, jeżeli wyborca nie ma dylematu, na którego jedynego kandydata może głosować. Nie ma obawy ,zmarnowania” głosu.

Sytuacja zmienia się w systemie opartym na większości bezwzględnej. Zwycięzcami w takim systemie głosowania są ci kandydaci, którzy kolejno uzyskali największą liczbę głosów i mieszczą się w liczbie mandatów przewidzianych do obsadzenia w danym okręgu wyborczym. Dodatkowo jednak muszą równolegle spełnić kolejny wymóg, a mianowicie każdy z nich musi uzyskać ponad połowę ważnie oddanych głosów. W tym systemie rozproszenie głosów pomiędzy kandydatami z tej samej listy może powodować, iż nie otrzymają oni ponad połowy głosów wyborców i tym samym nie uzyskają mandatów. Komitet wyborczy nie będzie więc skłonny do ryzyka i nie zgłosi kandydata, który jego zdaniem ma mniejsze szanse zwycięstwa. Tym samym trudniej w tym systemie przebić się mniej znanym politykom. Problem ten dotyczy w szczególności kandydatek.

W systemach stawiających wymóg uzyskania bezwzględnej większości głosów zawsze przewiduje się możliwość powtórnego głosowania w sytuacji kiedy żaden z kandydatów lub mniejsza ich liczba niż liczba mandatów do obsadzenia spełniła wymóg uzyskania bezwzględnej większości głosów. W tym przypadku z reguły określa się dodatkowe kryteria, których spełnienie jest niezbędne do przejścia kandydatów do drugiej tury głosowania. Zazwyczaj jest to wymóg uzyskania w turze pierwszej określonego procentowo poparcia wyborców lub np. do tury drugiej przechodzi określona liczba kandydatów z tury pierwszej, którzy otrzymali największą liczbę głosów. W systemie tym istnieje więc możliwość zdobycia mandatów przez wielu kandydatów, a tym samym szansę mają również ci z nich, którzy nie są zaliczani do faworytów. Tak więc ten system sprzyja umieszczaniu również kobiet na listach wyborczych.

\section{Kwoty dotyczące wyników}

Zgłaszanie kandydatów i procedury wyborcze to bez wątpienia ważna część elekcji. Jednak najważniejszy jest jej rezultat końcowy, czyli wyłonienie zwycięzców. W tym zakresie można wskazać na kilka sposobów zapewnienia udziału kobiet w sprawowaniu władzy. Do podstawowych, najczęściej stosowanych praktyk należy określenie kwot płci dotyczących 
podziału mandatów. Można wskazać na pięć podstawowych i jednocześnie najczęściej stosowanych rozwiązań w tym zakresie. Są to kwoty wyrażone w:

- liczbie mandatów;

- procencie mandatów;

- osobnej liście kobiecej;

- osobnym kobiecym okręgu wyborczym;

- systemie najlepszego przegranego.

Pierwsze rozwiązanie jest bardzo proste. Kobiety muszą objąć minimum określoną wcześniej liczbę mandatów. W niektórych państwach liczbę tę określa się ustawowo. W innych ustala się ją dopiero po głosowaniu. To drugie rozwiązanie najczęściej jest przyjmowane w państwach, w których zmienia się liczba deputowanych. Dzieje się tak np. wtedy, gdy skład liczebny organu wybieralnego zależny jest od liczby obywateli lub uprawnionych wyborców.

Rozwiązanie drugie jest w swej istocie bardzo zbliżone do poprzedniego, tyle że nie określa się kwot w liczbie mandatów, tylko procentowo do ogólnej liczby deputowanych. W tym przypadku nie ma znaczenia zmieniająca się liczba wybieranych do danego organu osób.

Rozwiązaniami znacznie rzadziej spotykanymi w praktyce są osobne listy wyborcze z których mogą kandydować wyłącznie kobiety oraz na tych samych zasadach tworzone odrębne dla kobiet okręgi wyborcze. Takie rozwiązanie na pewno jest skuteczne, ale budzi wątpliwości, bowiem tworzenie odrębnych list czy okręgów wyborczych dla kobiet i mężczyzn wyraźnie narusza zasadę równości płci.

Interesujący jest ostatni z przywołanych systemów, a mianowicie system najlepszego przegranego. Polega on na tym, że jeżeli ustalona wcześniej kwota dla danej płci nie została wypełniona w drodze równoprawnej rywalizacji, to brakujące mandaty do wypełnienia kwoty zostają obsadzone przez te kandydatki, które mandatu nie uzyskały, ale otrzymały kolejno największą liczbę głosów. Otrzymują mandaty również wtedy, jeżeli kandydaci mężczyźni uzyskali więcej od nich głosów wyborców. Komitet wyborczy po wyborach, aby wypełnić przepis dotyczący kwoty płci, dokonuje zmiany mandatu, który przypadł mężczyźnie i oddaje go kobiecie, która miała kolejno najlepszy wynik na tej samej liście (Larserud, Taphorn, 2013, s. 17).

Z powyższego zestawienia wynika, iż dobór odpowiedniego sposobu podziału mandatów ma zasadnicze znaczenie dla praktycznej realizacji koncepcji zapewnienia odpowiedniej kwoty płci. System ten jest funkcjo- 
nalny tylko wtedy, jeżeli przynosi zaplanowane rezultaty. W tym przypadku chodzi o zapewnienie określonego poziomu reprezentacji kobiet w organach władzy państwowej pochodzących z wyborów powszechnych. Tak więc poprzedzające ostateczną decyzję o przyznaniu mandatu działania na rzecz kwot płci nie mają zasadniczego znaczenia, jeżeli nie przynoszą spodziewanego efektu w postaci obecności kobiet w organach przedstawicielskich.

\section{Reprezentacja polityczna kobiet w Polsce}

Czy może istnieć system zakładający kwoty płci nie przynoszący rezultatów w postaci zwiększenia reprezentacji kobiet w organach wybieralnych? Oczywiście tak. Wystarczy, że koncepcja nie będzie realizowana całościowo, a tylko fragmentarycznie. $Z$ taką sytuacją mamy do czynienia obecnie w Polsce. Ustawa nakłada na komitety wyborcze wprowadzenie na listy kandydatów w wyborach do Sejmu minimum 35\% kobiet (lub umieszczeniu 35\% mężczyzn). I na tym kończą się regulacje prawne. Oznacza to, iż po spełnieniu wymogu kwoty płci komitet wyborczy nie musi podejmować żadnych działań, aby kandydatki uzyskały mandat. Jest to więc rozwiązanie prawne niegwarantujące zamierzonego rezultatu. Może mieć ono w wielu przypadkach tylko formalny, techniczny charakter. Komitet wyborczy nie musi dołożyć żadnych specjalnych starań na rzecz sukcesu wyborczego kobiet umieszczonych na jego listach kandydatów.

Jeżeli ustawodawca miał rzeczywisty zamiar doprowadzić do zwiększenia udziału kobiet w organach władzy ustawodawczej, to powinien zagwarantować skuteczną realizację zasady kwot płci. Tym samym do ustawodawstwa należy wprowadzić dodatkowe zasady gwarantujące zwiększenie liczby kobiet w parlamencie.

W 2013 roku zgłoszono dwa poselskie projekty dotyczące regulacji prawnych we wspomnianej kwestii. Nasz Ruch proponuje ustanowienie zasady zobowiązującej komitety wyborcze do wprowadzenia na zgłaszanych listach kandydatów parytetu płci (50\% kobiet i 50\% mężczyzn). W przypadku nieparzystej liczby osób kandydujących, liczba kobiet i mężczyzn nie mogłaby się różnić więcej niż o jedną osobę.

Partia proponuje także, aby kobiety i mężczyźni zajmowali na liście wyborczej miejsca naprzemiennie. Podobne rozwiązanie znalazło się w zgłoszonym przez posłanki z Parlamentarnej Grupy Kobiet projekcie 
zmian prawa wyborczego. Grupa parlamentarzystek z Platformy Obywatelskiej, Polskiego Stronnictwa Ludowego, Sojuszu Lewicy Demokratycznej i Naszego Ruchu chce, aby kobiety i mężczyźni zajmowali na liście wyborczej miejsca na przemian, jednak tylko do wyczerpania 35\% kwoty. Wynika z tego, iż same kobiety są mniej radykalne w żądaniach niż Nasz Ruch (Parlamentarna Grupa Kobiet za metoda ,, suwakowq”, 2013).

Platforma Obywatelska już obecnie stosuje zasadę, która zapewnia kobietom miejsca w czołówce list wyborczych. W pierwszej piątce muszą być przynajmniej dwie osoby tej samej płci, a w pierwszej trójce najwięcej dwie.

Warto także przypomnieć, iż jeszcze przed wprowadzeniem ustawowego wymogu kwotowego, niektóre partie wprowadziły własne, wewnętrzne regulacje dotyczące tej kwestii. Już w 2001 roku trzy ugrupowania: SLD, Unia Pracy oraz Unia Wolności zadecydowały, iż na ich listach wyborczych musi być co najmniej 30\% kobiet $^{3}$. Rezultat tych regulacji był widoczny natychmiast. W wyborach w 2001 roku odsetek kobiet na listach wyborczych do Sejmu wyniósł 23,2\% a do Senatu 14,7\%. Bardziej szczegółowo przedstawiono to $\mathrm{w}$ tabeli 1 .

Tabela 1

Kobiety zgłoszone na listach kandydatów w wyborach do parlamentu w Polsce (w \%)

\begin{tabular}{||c|l|l||}
\hline Rok wyborów & Sejm & Senat \\
\hline 1997 & 15,7 & 10,4 \\
\hline 2001 & 23,2 & 14,7 \\
\hline 2005 & 24,5 & 15,9 \\
\hline 2007 & 23,08 & 11,95 \\
\hline 2011 & 43,54 & 14,00 \\
\hline
\end{tabular}

Źródło: Opracowanie własne.

Od 1991 r. aż do wyborów w 1997 roku ordynacje wyborcze do Sejmu przewidywały obsadzanie 69 mandatów z list ogólnopolskich. Taką listę kandydatów mógł zgłosić tylko ogólnopolski komitet wyborczy. Mandaty z list ogólnopolskich obsadzane były w proporcji do uzyskanej liczby

3 We wcześniejszych wyborach w 1997 roku najwięcej kobiet było na listach UP $(24,9 \%)$ i Unii Wolności $(18,6 \%)$ oraz SLD $(15,1 \%)$. W 2001 roku na listach koalicji SLD-UP kobiety stanowiły 36,16\%, Unii Wolności - 31,25\%, Ligi Polskich Rodzin $-24,82 \%$, Samoobrony - 20,48\%, PSL - 19,34\%, Prawa i Sprawiedliwości - 17,42\%, PO - 17,06\%, Akcji Wyborczej Solidarność - 14,71\%. 
głosów przez komitet wyborczy w skali kraju. Była to dodatkowa premia dla największych komitetów wyborczych. Mandaty z listy ogólnopolskiej konkretnego komitetu wyborczego przypadały tym kandydatom, których nazwiska znajdowały się na początku listy ogólnopolskiej komitetu wyborczego i mieściły się w liczbie mandatów, które przypadły temu komitetowi wyborczemu w ramach podziału 69 mandatów przeznaczonych do obsadzenia z list ogólnopolskich (Stelmach, 1997, s. 64).

Listy ogólnopolskie dawały możliwość wejścia do Sejmu również tym kandydatom, którzy uzyskali bardzo słaby wynik w okręgu wyborczym. Jednocześnie umieszczenie nazwiska na liście ogólnopolskiej stanowiło o prestiżu i pozycji kandydata w ugrupowaniu politycznym. W 1997 roku na 10 komitetów wyborczych, które zgłosiły swoje listy ogólnopolskie, połowa nie umieściła żadnej kobiety w pierwszej dziesiątce miejsc na liście, trzy - na pierwszych dwudziestu miejscach, a zwycięskie w tych wyborach ugrupowanie Akcja Wyborcza Solidarność nie miała na swej liście ogólnopolskiej żadnej kobiety na pierwszych trzydziestu miejscach (Program Narodów Zjednoczonych ds. Rozwoju, 2007. s. 26).

Jak wynika z badań przeprowadzonych przez CBOS w lutym 2013 roku, wśród badanych przeważały opinie, że więcej kobiet niż obecnie powinno zajmować odpowiedzialne stanowiska w rządzie (47\%), w fundacjach i organizacjach społecznych (również 47\%), w partiach politycznych (46\%), w administracji państwowej (42\%), a także w firmach i przedsiębiorstwach (45\%) (CBOS, 2013, s. 1).

$\mathrm{Na}$ uwagę zasługuje systematyczny, stały wzrost wspomnianych wskaźników w kolejnych latach, w których przeprowadzano badanie. Obrazują to wyniki podane w tabeli 2,3 i 4 .

Tabela 2

Odpowiedź na pytanie: czy, Pana(i) zdaniem, więcej, tyle samo czy też mniej kobiet niż obecnie powinno zajmować kierownicze stanowiska w rządzie

\begin{tabular}{||c|c|c|c|c||}
\hline Lata & Więcej niż obecnie & Tyle samo & Mniej niż obecnie & Trudno powiedzieć \\
\hline 1992 & 41 & 31 & 14 & 15 \\
\hline 1995 & 40 & 34 & 11 & 14 \\
\hline 1997 & 44 & 31 & 11 & 14 \\
\hline 1999 & 43 & 41 & 3 & 13 \\
\hline 2006 & 50 & 31 & 4 & 15 \\
\hline 2013 & 47 & 32 & 8 & 13 \\
\hline
\end{tabular}

Źródło: Opracowanie własne na podstawie Kobiety w życiu publicznym, Komunikat z badań CBOP, BS/34/2013. 
Tylko w pytaniu dotyczącym zwiększenia liczby kobiet w rządzie nastąpił niewielki regres. W 2006 roku za zwiększeniem reprezentacji kobiet opowiadało się 50\% respondentów, a w 2013 tylko 47\%. Podwoił się także odsetek respondentów, którzy uważali, że ta liczba powinna ulec zmniejszeniu (z 4\% do 8\%). Można domniemywać, że te zmiany spowodowane były zwiększeniem się liczby kobiet zajmujących eksponowane stanowiska w organach władzy państwowej pomiędzy 2006 a 2013 rokiem.

Tabela 3

Odpowiedź na pytanie: czy, Pana(i) zdaniem, więcej, tyle samo czy też mniej kobiet niż obecnie powinno zajmować kierownicze stanowiska w partiach politycznych

\begin{tabular}{||c|c|c|c|c||}
\hline Lata & Więcej niż obecnie & Tyle samo & Mniej niż obecnie & Trudno powiedzieć \\
\hline 1992 & 27 & 32 & 20 & 21 \\
\hline 1995 & 26 & 35 & 21 & 18 \\
\hline 1997 & 32 & 32 & 18 & 18 \\
\hline 1999 & 35 & 42 & 7 & 16 \\
\hline 2006 & 45 & 31 & 7 & 17 \\
\hline 2013 & 46 & 32 & 7 & 15 \\
\hline
\end{tabular}

Źródło: Opracowanie własne na podstawie Kobiety w życiu publicznym, Komunikat z badań CBOP, BS/34/2013.

Tabela 4

Odpowiedź na pytanie: czy, Pana(i) zdaniem, więcej, tyle samo czy też mniej kobiet niż obecnie powinno zajmować kierownicze stanowiska w administracji państwowej

\begin{tabular}{||c|c|c|c|c||}
\hline \hline Lata & Więcej niż obecnie & Tyle samo & Mniej niż obecnie & Trudno powiedzieć \\
\hline 1992 & 30 & 40 & 16 & 14 \\
\hline 1995 & 28 & 46 & 12 & 15 \\
\hline 1997 & 36 & 42 & 8 & 14 \\
\hline 1999 & 33 & 50 & 4 & 12 \\
\hline 2006 & 40 & 39 & 6 & 15 \\
\hline 2013 & 42 & 40 & 6 & 12 \\
\hline
\end{tabular}

Źródło: Opracowanie własne na podstawie Kobiety w życiu publicznym, Komunikat z badań CBOP, BS/34/2013.

Symptomatyczny jest również spadek liczby osób, które uważają, iż liczba kobiet zajmujących wysokie stanowiska powinna ulec zmniejszeniu. Dzisiaj ten odsetek wynosi od 6 do $8 \%$. 
Bardzo interesujące, ze względu na temat niniejszego opracowania, są poglądy Polaków dotyczące prawnych regulacji systemu kwotowego płci na listach wyborczych. Za takim rozwiązaniem opowiada się ogółem 32\% respondentów. $Z$ tego $11 \%$ zdecydowanie, a $21 \%$ raczej popiera takie rozwiązanie. Przeciwnego zdania jest 59\% respondentów. $Z$ tego $32 \%$ jest raczej przeciwna prawnej regulacji dotyczącej kwot płci na listach wyborczych, a $27 \%$ nawet zdecydowanie opowiada się przeciwko takim rozwiązaniom prawnym (CBOS, 2013, s. 6).

Respondentów opowiadających się za kwotowym udziałem kobiet na listach wyborczych ankieterzy zapytali, jaki procent, ich zdaniem, powinny na listach wyborczych stanowić kobiety. Ankietowani najczęściej (47\%) odpowiadali, że połowę, a nieco rzadziej (43\%), że mniej niż połowę. Jedynie nieliczni badani (6\%) uważali, że w wyniku prawnych ustaleń kobiety powinny mieć zapewnione więcej niż połowę miejsc na listach wyborczych. Średnio ankietowani oceniali, że kobiety powinny otrzymać na listach wyborczych 40\% miejsc (CBOS, 2013, s. 7).

\section{Wnioski}

Jak wskazuje doświadczenie państw, w których doprowadzono do wyrównania reprezentacji politycznej kobiet i mężczyzn w organach władzy państwowej, najbardziej skuteczna jest metoda wprowadzania odpowiednich regulacji prawnych do ordynacji wyborczych. Tą drogą można doprowadzić do osiagnięcia parytetu płci np. w parlamencie czy innych organach wybieranych w wyborach powszechnych.

Wydaje się, iż docelowym, realnym dążeniem w Polsce, powinno być uzyskanie wskaźnika kwoty płci dla kobiet na poziomie 30-40\%. W wyniku wyborów parlamentarnych przeprowadzonych w 2011 roku wskaźnik ten dla Sejmu wynosi $24 \%$, a dla Senatu tylko $13 \%$. Są to wyniki znacznie gorsze od oczekiwanych, chociaż, co już wcześniej podkreślano, w przypadku Sejmu mamy do czynienia z tendencją zwyżkową w porównaniu do wcześniejszych elekcji. W Senacie lepszy rezultat od obecnego uzyskano tylko w 2001 roku. Wtedy w wyższej izbie parlamentu zasiadały aż 23 panie.

To co jest pozytywne, to zwiększająca się liczba kobiet kandydujących do Sejmu. W 2011 roku na listach kandydatów zajmowały one aż 43,54\% miejsc. Efekt końcowy w postaci liczby mandatów nie był już tak imponujący, ale coraz powszechniej zgłaszane przez różne siły poli- 
tyczne propozycje zwiększenia kwoty płci nawet do 50\% na listach wyborczych i wprowadzenie ustawowego wymogu stosowania metody suwakowej, daje poważne szanse na znaczne zwiększenie reprezentacji kobiet w Sejmie.

Tabela 5

Kobiety w parlamencie w Polsce od 1989 roku (w \%)

\begin{tabular}{|c|c|c|}
\hline Rok wyborów & Sejm & Senat \\
\hline 1989 & 13 & 7 \\
\hline 1991 & 10 & 8 \\
\hline 1993 & 13 & 13 \\
\hline 1997 & 13 & 12 \\
\hline 2001 & 20 & 23 \\
\hline 2005 & 15 & 9 \\
\hline 2007 & 19 & 8 \\
\hline 2011 & 24 & 13 \\
\hline
\end{tabular}

Źródło: Opracowanie własne.

Wydaje się, że w szczególności obligatoryjność stosowania metody suwakowej na listach wyborczych powinna przynieść poprawę wskaźnika reprezentacji kobiet w Sejmie. Jeżeli dodamy do tego bardzo duże poparcie dla zwiększenia reprezentacji kobiet w organach władzy i kierownictwach partii politycznych, to po najbliższych wyborach parlamentarnych możemy spodziewać się znacznego wzrostu liczby kobiet w Sejmie i Senacie.

\section{Bibliografia}

CBOP (2013), Kobiety $w$ życiu publicznym, Komunikat z badań CBOP, BS/34/2013 (online), Warszawa, http://www.cbos.pl/SPISKOM.POL?2013/K_034_13.PDF (dostęp: 20.12.2013).

Dahlerup D. (2007), Electoral Gender Quotas: Between Equality of Opportunity and Equality Results, „Representation”, nr 43/2.

Komisja Praw Kobiet i Równouprawnienia Parlamentu Europejskiego (2008), Kwoty dotyczace ptci w systemach wyborczych w Europie. Raport Parlamentu Europejskiego, Dyrekcja Generalna ds. Polityki Wewnętrznej Unii Europejskiej. 
Larserud S., Taphorn R. (2013), Planowanie na rzecz równości. Najkorzystniejsze, średnio korzystne i najmniej korzystne połaczenia systemów wyborczych $i$ kwot dotyczacych ptci, Instytut Spraw Publicznych, Warszawa.

Program Narodów Zjednoczonych ds. Rozwoju (2007), Polityka równości ptci. Polska 2007. Raport, Fundacja „Fundusz Współpracy”, Warszawa.

Stelmach A. (1997), Zmiana prawa wyborczego w Polsce w okresie tranzycji systemowej, „Problemy Humanistyki”, nr 2.

Ustawa z dnia 5 stycznia 2011 r. Kodeks wyborczy, Dz. U. 2011, Nr 21, poz. 112, art. $197 \S 1$.

Parlamentarna Grupa Kobiet za metodq ,,suwakowq”, http://wiadomości.onet.pl. /kraj/parlamentarna-grupa-kobiet-ze-metoda-suwakowa (dostęp: 28.12.2013).

\section{The mechanisms for increasing women's participation in elections}

\section{Summary}

The degree to which women are represented in the organs of national authorities stirs considerable emotions. Proposals for legal regulations providing guarantees for the adequate representation of women in parliament are presented more and more often. The paper analyzes the means and methods for increasing women's participation in politics, with particular attention placed on how this is provided for in electoral law. The paper places particular attention on the situation in Poland. 